\title{
KEMASLAHATAN DALAM PERLINDUNGAN HUKUM TERHADAP KONSUMEN DAN PELAKU USAHA MELALUI MEKANISME PENETAPAN HARGA OLEH NEGARA
}

\author{
Mhd. Erwin Munthe \\ STIE Syariah Bengkalis \\ Email: bmtherwinmunthe@gmail.com
}

\section{Abstract}

In business competition there are often monopolistic activities which result in high prices for the game of business actors. This makes consumers uneasy because they do not get varied prices and fair prices, while for small business actors they do not have competitive ability. The existence of monopolistic practices and unfair competition is not in line with the constitution. Because the 1945 Constitution mandates that the national economy must be carried out by promoting people's welfare. Therefore, the presence of the government is very necessary to realize the ideals mandated by the constitution and legislation. This study aims to analyze the mechanism and criteria for pricing by the state. The result is providing legal protection to consumers and other business actors, the government sets the highest retail price and the lowest retail price and provides subsidies to imported products that control the liveliboods of many people. This effort is carried out to realize mutual benefit between producers and consumers.

Dalam persaingan usaha sering terdapat kegiatan-kegiatan monopoli yang mengakibatkan tingginya harga atas permainan pelaku usaha. Hal ini membuat kegelisahan konsumen karena tidak mendapatkan harga yang variatif dan wajar, sedangkan bagi pelaku usaha kecil tidak memiliki kemampuan bersaing. Adanya praktik monopoli dan persaingan tidak sehat ini tidaklah sejalan dengan konstitusi. Karena UUD 1945 mengamanatk an bahwa perekonomian nasional harus dijalankan dengan mengedepankan kesejahteraan rakyat. Oleh karenanya, kehadiranpemerintah sangat diperlukan untuk mewujudkan cita-cita yang diamanatkan konstitusi dan peraturan perUndang-Undangan. Penelitian ini bertujuan untuk menganalisis 
mekanisme dan kriteria penetapan harga oleh negara. Sementara metodenya penelitian doktrinal dalam bentuk penelitian evaluatif. Pendekatan yang digunakan adalah pendekatan perUndang-Undangan. Hasil penelitian ini adalah bahwa dalam memberikan perlindungan bukum kepada konsumen dan pelaku usaba lainnya, pemerintah menetapkan harga eceran tertinggi dan harga eceran terendah serta memberikan subsidi pada produk-produk impor yang menguasai hajat hidup orang banyak. Upaya ini dilakukan untuk mewujudkan kemaslahatan bersama antara produsen dan konsumen.

Keywords: legal protection, consumers and businesses actors, pricing mechanism

\section{Pendahuluan}

Berbicara tentang perlindungan konsumen dalam bisnis maka berbicara pula tentang harga. Bagi pelaku usaha (produsen) semestinya harga yang ditetapkan haruslah wajar. Artinya, melalui perhitungan yang matang, benar atas seluruh biaya yang dikeluarkan dan dari seluruh keuntungan yang akan diperoleh. Kedudukan sebagai satu-satunya produsen (monopolist) tidak dapat dijadikan sebagai alasan untuk menetapkan harga setinggi mungkin. Produk dan harga harus mempunyai nilai yang sama, sehingga pelaku usaha sama beruntung dan tidak dirugikan. ${ }^{1}$

Bagi pelaku usaha lainnya, harga yang ditetapkan itu haruslah wajar sehingga tidak ada perasaan sengaja dipinggirkan, digusur, atau dimatikan karena harga yang terlalu rendah. Di sisi lain, kedudukan sebagai pelaku besar (kuat) tidak boleh dipakai untuk memerangi permainan harga terhadap pelaku usaha lainnya. ${ }^{2}$ Terkait dengan penetapan harga telah diatur dalam UU No. 5 Tahun 1999 tentang Praktek Monopoli dan Persaingan Usaha Tidak Sehat (disingkat UU Persaingan Usaha). Peraturan ini lahir untuk menjaga pasar agar tetap terbuka, dan tidak terdistorsi oleh kegiatan-kegiatan monopoli, dan untuk menciptakan iklim persaingan usaha sehat. Senada dengan upaya pemerintah, persaingan tidak sehat berbentuk monopoli atau biasa disebut ibtikâr dalam tatanan hukum Islam juga dilarang. Larangan ini dikatakan telah mencapai konsensus para ulama. ${ }^{3}$

Argumentasi yang dibangun para ulama dalam mengharamkan monopoli tidak hanya berdasar pada dalil naql ( $Q s$. al-Hajj: 22) tetapi juga bersumber pada dalil ' $a q l$. Para ulama berpendapat bahwa monopoli erat kaitannya dengan hajat hidup orang banyak. Larangan monopoli lantaran menghambat masyarakat dalam memenuhi kebetuhan mereka. Kalaupun terpenuhi mereka akan mendapatkannya dengan

1 Janus Sidabalok, Hukum Perlindungan Konsumen di Indonesia (Bandung: Citra Aditya Bakti, 2014), h. 222-223.

2 Janus Sidabalok, Hukum Perlindungan Konsumen di Indonesia, h. 223.

3 Erwandi Tarmidzi, Harta Haram Muamalat Kontemporer (HHMK), (Bogor: Berkat Mulia Insani, 2012), h. 207-209. 
harga relatif tinggi. Selain itu, monopoli hanya memberikan kemaslahatan individu, bukan kemaslahatan umum. Apabila terjadi benturan antara kemaslahatan individu dengan kemaslahatan umum, maka kemaslahatan umum harus didahulukan. ${ }^{4}$

Tidak termasuk monopoli jika dilakukan pada situasi pasokan barang sedang melimpah. ${ }^{5}$ Contohnya saat terjadi panen besar, dan segera menjualnya ketika pasar membutuhkannya. Contoh lain melakukan penimbunan barang dengan tujuan untuk memenuhi kebutuhan keluarganya dan bukan untuk dijual dengan harga tinggi ketika masyarakat sangat membutuhkannya. ${ }^{6} \mathrm{Hal}$ ini beralasan, sebab dalam situasi panen besar, apabila tidak ada pihak yang bersedia membeli/menampung hasil panen tersebut, dapat mengakibatkan harga pasar akan semakin melemah. Hal tersebut justru akan merugikan petani yang dalam hal ini merupakan pemasok terbesar.

Jika ditinjau dari sejarah politik gerakan kemerdekaan, falsafah bangsa, dan konstitusi, Indonesia adalah negara demokrasi, termasuk pula demokrasi ekonomi. Pancasila sebagai ideologi bangsa Indonesia bahkan mengandung tidak kurang dari tiga sila yang melandasi demokrasi, yaitu sila perikemanusiaan, sila permusyawaratan dan perwakilan untuk mufakat, dan sila keadilan sosial. Terkait dengan demokrasi ekonomi pembukaan UUD 1945 memiliki visi umum untuk mewujudkan masyarakat adil dan makmur. Artinya kemakmuran merupakan dari cita-cita bangsa dimana kelimpahan ekonomi dan kesejahteraan merupakan citacita yang harus dicapai. Kemakmuran yang berdasar pada keadilan bagi seluruh rakyat. Artinya dalam demokrasi Indonesia, rakyat Indonesia hendak mencapai masyarakat yang adil, makmur secara merata dengan menghindari perbedaanperbedaan yang mencolok dan cara-cara yang ekstrem. ${ }^{7}$

Permasalahan dalam penerapan demokrasi dewasa ini adalah hukum tidak bebas nilai dan netral. Hukum dari proses pembuatan sampai pemberlakuannya selalu mengandung pemihakan. Proses-proses hukum bekerja dalam realitas yang tidak netral dan nilai yang ada di belakangnya adalah subyektif. Seringkali hukum dilingkupi oleh kepentingan-kepentingan tertentu diluar kepentingan ideal hukum. Pada hukum persaingan usaha tidak jarang lahir koalisi antar pelaku

4 Sebagaimana yang dikemukakan oleh Hanafiyyah, Syafíiyyah, Hanabilah, dan Malilikiyyah. al-Mughni>, Juz IV, h. 283. dalam Dede Abdul Fatah, "Monopoli dalam Perspektif Ekonomi Islam," Al-Iqtishad: Vol. IV, No. 2, (Juli, 2012), h. 7.

5 Dede Abdul Fatah, "Monopoli dalam Perspektif Ekonomi Islam", h. 8.

6 Al-Baji, al-Muntaqa > Syarh al-Munaththa', Juz V, 15. dalam Dede Abdul Fatah, "Monopoli dalam Perspektif Ekonomi Islam, h. 8-9.

7 Erlina Septiyaningrum, "Politik Hukum Persaingan Usaha Dalam Kerangka Demokrasi Indonesia (Suatu Kajian Sejak Orde Lama Hingga Orde Reformasi)", Tesis, Program Pascasarjana Universitas Sebelas Maret, Surakarta, 2013, h. 12-13. 
usaha dengan pemerintah untuk membentuk hukum yang dapat mengamankan kepentingan mereka. Namun tak jarang negara tidak begitu kuat menghukum para pelaku besar ketika melakukan kesalahan. Karena itu, demokrasi ekonomi sebagai perekonomian nasional hanya dinikmati oleh segelintir orang. Hal inilah yang oleh Didik J Rachbini disebut sebagai "negara hadir dalam pasar ketika perannya tidak diperlukan dan melakukan perannya ketika tidak diperlukan".

Hadirnya kepentingan-kepentingan di atas diluar kepentingan ideal hukum. Oleh karena kebijakan pemberlakuan peraturan perUndang-Undangan akan berdampak pada kebijakan-kebijakan lainnya: kebijakan dalam menetapkan harga seperti operasi pasar, pemberian subsidi/BLT, pemberlakuam harga pemerintah, pengaturan bea masuk impor dan pengaturan barang ekspor. Kebijakan-kebijakan tersebut dan aturan yang mengaturnya akan sangat berpengaruh pada tercapainya demokrasi ekonomi. Misalnya saja tentang persaingan usaha yang telah diatur dalam UU Nomor 5 Tahun 1999 tentang Larangan Praktek Monopoli dan Persaingan Usaha Tidak Sehat, UU Nomor 8 Tahun 1999 tentang Perlindungan Konsumen yang tidak terlepas dari kepentingan berupa bantuan dana dari International Monitory Fund (IMF).

Dengan demikian dapat ditarik kesimpulan bahwa cabang-cabang produksi yang melibatkan hajat hidup orang banyak dikuasi oleh negara. Dikuasai oleh negara menurut Muhammad Hatta tidak berarti negara menjadi pengusaha namun lebih tepat membuat peraturan' ataupun kebijakan dengan penetapan harga untuk barang dan jasa yang dibawah badan usaha milik negara. Sementara barang-barang dan jasa yang tidak secara langsung ditetapkan harga oleh negara diatur oleh subsidi, bai itu subsidi ekspor maupun subsidi impor. Sementara untuk menjamin efisiensi, melindungi hak-hak konsumen, pemerataan dan stabilitas ekonomi, maka fungsi negara mutlak diperlukan dalam perekonomian sebagai pengendali mekanisme pasar. Adapun permasalahan yang muncul dalam penelitian adalah: Bagaimana mekanisme penetapan harga dan kriterianya yang diatur oleh negara dalam rangka memberikan perlindungan hukum kepada konsumen dan pelaku usaha lainnya dalam mewujudkan persaingan usaha sehat.

\section{Metode Penelitian}

8 Erlina Septiyaningrum, "Politik Hukum Persaingan Usaha Dalam Kerangka Demokrasi Indonesia (Suatu Kajian Sejak Orde Lama Hingga Orde Reformasi)”, h. 15.

9 Firdaus, Tanggung Jawab Sosial dan Lingkungan Perseroan Terbatas Terhadap Hak Asasi Manusia (Study Tentang Tanggung Jawab Sosial dan Lingkungan Perusabaan Perkebunan Kelapa Sawit Terhadap Hak Ekonomi dan Sosial Masyarakat Lokal di Provinsi Riau, Disertasi, Program Pascasarjana Universitas Islam Indonesia, Yogyakarta, 2013. 
Jenis penelitian ini termasuk penelitian hukum normatif atau biasa disebut dengan penelitian doktrinal dalam bentuk penelitian evaluatif. Penelitian doktrinal merupakan penelitian yang menyediakan ekspos sistematis terhadap peraturan yang mengatur kategori hukum tertentu, menganalisis hubungan antar peraturan dan menjelaskan area yang mengalami hambatan serta memperkirakan perkembangan mendatang. ${ }^{10}$ Sementara bentuk evaluatif dalam penelitian ini, penulis ingin mengetahui program-program atau kebijakan-kebijakan yang negara dilakukan atau diterapkan dalam hal penetapan harga sehingga memberikan perlindungan hukum kepada konsumen dan pelaku usaha. Pendekatan yang digunakan adalah pendekatan perUndang-Undangan (statute approach). Pendekatan ini dilakukan dengan menelaah semua Undang-Undang dan regulasi yang berkaitan dengan persaingan usaha sehat.

\section{Pembahasan}

\section{Perlindungan Hukum Kepada Konsumen dan Pelaku Usaha Sebagai Upaya Mewujudkan Persaingan Usaha Sehat}

Kebijakan negara dalam menciptakan pasar yang kondusif dan mengantarkan kesejahteraan sebesar-besarnya untuk masyarakat melalui UU Perlindungan konsumen, UU Persaingan usaha maupun penetapan harga telah mewajibkan pelaku usaha untuk melaksanakan persaingan yang sehat. Namun mekanisme penetapan harga oleh negara terhadap produk atau jasa belum bisa berjalan secara maksimal, hal ini dikarenakan belum diaturnya mekanisme secara terperinci dan komprehensif.

Mekanisme penetapan harga yang dilakukan oleh negara secara teoritis adalah dengan penetapan harga maksimum atau harga eceran tertinggi (HET) yang bertujuan untuk melindungi konsumen. Penetapan harga ini ditujukan untuk produk dan jasa yang diproduksi oleh badan usaha milik negara seperti tarif harga $\mathrm{BBM}$, tarif tiket KA, tiket pesawat maupun produk lainnya seperti komoditas pangan. Hal ini sesuai dengan amanat UUD 1945 bahwa hal-hal yang penting bagi negara menyangkut hajat hidup orang banyak dikuasai oleh negara. Ini menjadi alasan mengapa negara berhak memonopoli pasar dan perlu membuat kebijakan harga maksimum yang tidak mencekik masyarakat luas.

Komoditas pangan meliputi beras, kedelai sebagai bahan baku, tempe, cabai, bawang merah, daging sapi, dan lainnya sebenarnya telah diatur dalam Peraturan

10 Abdulkadir Muhammad, Hukum dan Penelitian Hukum, Cet. 1 (Bandung: PT. Citra Aditya Bakti, 2004), h. 52. 
Presiden (Perpres). Perpres ini merupakan amanah UU No.7 Tahun 2014 tentang Perdagangan, agar dapat mengendalikan persediaan bahan-bahan pokok pada waktu-waktu tertentu. Barang-barang dan jasa seperti ini menjadi domain negara untuk menetapkan dan mengintervensi harga. Sehingga diharapkan mampu meningkatkan kesejehteraan rakyat melalui harga yang stabil.

Jika pelaku usaha menetapkan harga melebihi harga normal dan harga persentase yang telah ditetapkan oleh pemerintah melalui peraturan-peraturan yang ada atau disebut dengan lonjakan harga maka negara memiliki kewenangan untuk mengintervensi harga. Misalnya pada beras, batas toleransi kenaikan harga hanya sampai $10 \%$. Di atas harga tersebut pemerintah dapat melakukan intervensi agar pelaku usaha dapat menurunkan harga. Batas toleransi ini diatur dalam Pasal 1 ayat 2 Peraturan Menteri Perdagangan Nomor 04/M-DAG/PER/I/2012 tentang Cadangan Beras Pemerintah Untuk Stabilisasi Harga. Batasan toleransi atau HET ini juga dapat disesuaikan pemerintah setempat dengan melihat harga normal di daerahnya dana atas dasar masukan dari dinas setempat.

Merujuk dari yang diamanatkan oleh konstitusi UUD 1945 bahwa penetapan harga tertinggi merupakan salah satu kebijakan negara dalam mewujudkan kesejahteraan sebesar-besarnya bagi rakyat dengan harga yang wajar dan terjangkau. Selain menetapkan harga HET, negara juga menetapkan harga minimum yang bertujuan untuk melindungi pelaku usaha. Pelaku usaha disini adalah pelaku usaha yang digandeng oleh pemerintah untuk menstabilkan harga pasar dan melindungi pelaku usaha dari persaingan yang tidak sehat. Seperti petani gabah kering yang oleh negara dibeli hasil gabahnya. Hal ini untuk melindungi petani dari pembeli dengan harga yang sangat murah dan dijual kembali dengan harga yang mahal. Jika pada harga tersebut tidak ada yang membeli, pemerintah akan membelinya melalui BULOG (Badan Usaha Logistik) kemudian didistribusikan ke pasar.

Secara garis besar ada beberapa kebijakan yang dilakukan pemerintah dalam memberikan perlindungan hukum kepada konsumen dan pelaku usaha lainnya diantaranya sebagai berikut:

\section{Pemberian Subsidi (Harga/BLT)}

Berbicara masalah pemberian subsidi oleh pemerintah tidak terlepas dari pembahasan konsep negara kesejahteraan (welfare state). Sebab dalam konsep negara kesejahteraan pemerintah sebagai pemegang kekuasaan tertinggi berkewajiban atau bertanggungjawab dalam mensejahterakan masyarakatnya melalui kebijakan-kebijakan. Dalam konteks Indonesia, negara mengadopsi konsep syari'ah yang diimplementasikan dalam bentuk lazis (lembaga amil zakat, infak dan shadaqah). 
Dasar yuridis Indonesia sebagai negara hukum tertera pada Pasal 1 ayat (3) Undang-Undang Dasar 1945 (amandemen ketiga), "negara Indonesia adalah negara hukum" konsep negara hukum mengarah pada tujuan terciptanya kehidupan demokratis, dan terlindunginya hak azasi manusia, serta kesejahteraan yang berkeadilan. Selain itu, terdapat bukti lain yang menjadi dasar yuridis bagi keberadaan negara hukum Indonesia dalam arti material yaitu pada Bab XIV Pasal 33 dan Pasal 34 UUD 1945 bahwa negara turut aktif dan bertanggung jawab atas perekonomian negara dan kesejahteraan rakyat.

Dengan merujuk fungsi negara yang menganut konsep negara kesejahteraan atau negara yang menganut konsep negara hukum kesejahteraan Indonesia, menyebabkan negara memegang peranan penting dalam mengimplemetasikan kesejahteraan tersebut. Guna memenuhi fungsinya sebagai pengatur dan sebagai wirausaha ${ }^{11}$, maka negara Indonesia terlibat dan diberi kewenangan sebagai wirausaha untuk bertindak langsung agar produksi-produksi yang menguasai hajat hidup orang banyak tidak dikuasai oleh segelintir orang.

Demikian halnya dalam bidang pengaturan. Negara mempunyai peranan penting untuk mengatur perekonomian di Indonesia agar menciptakan kesejahteraan rakyat melalui kebijakan-kebijakan yang berdasarkan atas hukum baik melalui kebijakan pemberian subsidi, operasi pasar, pengaturan bea masuk impor, pembatasan ekspor dan lainnya. Agar kebijakan-kebijakan ini berhasil, maka diperlukan instrumen yang dapat digunakan oleh negara dalam melaksanakan fungsinya sebagai pengatur termasuk dalam hal mekanisme penetapan harga oleh negara maka diperlukan asas legalitas dalam konsep negara berdasarkan atas hukum.

Jika memperhatikan konteks permasalahan subsidi, maka BBM salah satu sektor pemerintah yang diberikan subsidi akibat kenaikan harga. Misalnya pada tahun 2005 terjadi protes atas kenaikan harga BBM oleh sebagian besar masyarakat Indonesia atas kebijakan pemerintah Susilo Bambang Yudhoyono. Harga BBM subsidi pada saat itu mengalami kenaikan yang sangat fantastis Premuim Rp. 2.400 menjadi Rp. 4.500 Solar dari Rp. 2.100 menjadi Rp. 4.300, sedangkan minyak tanah tidak mengalami perubahan harga. Sementara pada tahun 2016 harga BBM telah mengalami penurunan harga satu kali. Pada 5 Januari lalu harga Premium Rp. 6.950 menjadi Rp. 6.450 pada 1 April, Solar 5.650 menjadi 5.150.

UU No. 22 Tahun 2001 tentang Minyak dan Gas Bumi merupakan salah satu peraturan hukum di bidang gas dan minyak bumi. Undang-Undang ini masih tetap dilaksanakan sampai saat ini sebagai landasan yuridis dalam pengaturan kegiatan di sektor minyak dan gas bumi. Terkait tentang subsidi BBM, UU Migas

11 Marsuni Lauddin, Hukum dan Kebijakan Perpajakan di Indonesia (Yogyakarta: UII Press, 2006), h. 46. 
membahas tentang golongan orang yang diperbolehkan untuk menikmati subsidi. Pasal 28 UU No. 22 Tahun 2001 tentang Minyak dan Gas Bumi menyatakan bahwa dalam menentukan dan menetapkan harga pemerintah mempunyai tanggungjawab sosial dengan golongan tertentu. Dengan demikian, subsidi BBM bukan untuk seluruh golongan masyarakat. Salah satu rinciannya dimuat dalam pasal 6 Peraturan Menteri ESDM No. 1 Tahun 2013, yang menyatakan subsidi BBM tidak boleh dinikmati kendaraan angkutan perkebunan dan pertambangan.

Dengan mempertimbangkan peraturan di atas, jelas subsidi diberikan secara umum kepada seluruh masyarakat tanpa mempertimbangkan kemampuan ekonomi, pada dasarnya bertentangan dengan Undang-Undang. Setelah gagalnya pemberian subsidi harga BBM kepada masyarakat, maka pemerintah mencoba untuk merubah mekanisme pemberian subsidi yaitu lewat kebijakan pemberian subsidi langsung atau yang disebut dengan Bantuan Langsung Tunai (BLT).

Namun kebijakan BLT pada BBM juga menuai kritikan. Seperti kurangya sosialisasi program BLT, distribusi kartu kompensasi BBM (KKB), mekanisme penyaluran BLT, ketepatan jumlah dana yang diterima, penggunaannya oleh rumah tangga yang miskin, dan persoalan lainnya. Bahkan kejadian menyebabkan meninggalnya seseorang akibat banyaknya massa yang berkerumun mengambil dana BBM tersebut. ${ }^{12}$ nKekacauan dan keterpurukan yang terjadi di masyarakat dalam pemberian subsidi harga atau BLT merupakan akibat keterpurukan hukum dan nilai nilai budaya permisif, idiotisme, feodalisme, dan berbagai isme-isme lainnya yang dijadikan jargon-jargon politik sehingga seamakin menunjukan keterpurukan negeri ini dengan proses idiotisme itu sendiri. ${ }^{13}$

Berbicara tentang kebijakan pemberian subsidi oleh negara, Jenkins merumuskan kebijakan negara sebagai serangkaian keputusan yang saling berkaitan yang diambil oleh seorang aktor politik atau sekelompok aktor politik. Berkenaan dengan tujuan yang telah dipilih beserta cara-cara untuk mencapainya, dalam situasi dimana keputusan-keputusan tersebut pada prinsipnya masih berada dalam batas-batas kewenangan para aktor tersebut. Kemudian Anderson mendefinisikan kebijakan publik sebagai kebijakan yang ditetapkan oleh badan-badan dan aparat pemerintah. $^{14}$

Kebijakan pemberian BLT untuk BBM hendaklah dipertimbangkan dengan matang. Kebijakan tersebut juga harus disesuaikan dengan kondisi di masyarakat, sehingga kebijakan pemberian subsidi benar-benar dapat membantu mengurangi

12 Abraham Amos, Kastropi Hukum dan Quo Vadis (Jakarta: Raja Grafindo Persada, 2007), h. 73.

13 Abraham Amos, Kastropi Hukum dan Quo Vadis, h. 73.

14 Wahyu Siswanti, "Dinamika Implementasi Kebijakan Bantuan Langsung Tunai”, Jurnal JKAP, Vol. 12 No. 1, (Mei, 2008), h. 24. 
kemiskinan rakyat dan memberikan kesejahteraan pada rakyat. Meski terkadang kebijakan-kebijakan yang dibuat pemerintah hanya memberikan solusi sementara. Hal ini disebabkan karena lebih mengedepankan idelogi politik saat berkampanye tanpa mempunyai konsep atau pertimbangan yang matang.

Pada awalnya pengaturan ekonomi oleh pemerintah dibiarkan bebas dan tunduk pada hukum persaingan pasar, yang menurut Spero sebagai "Natural Law". Tetapi setelah mengalami berbagai proses sosial, timbul pemikiran-pemikiran untuk melibatkan pemerintah di bidang ekonomi untuk melindungi golongan ekonomi lemah melalui hukum administrasi negara. Demikian pula bidang hukum yang awalnya hanya diatur oleh hukum perdata, telah banyak diterobos oleh hukum administrasi negara untuk memberikan suasana yang lebih adil bagi pihak-pihak yang berperan dalam lalu lintas ekonomi. ${ }^{15}$

Dampak dari sebuah kesejahteraan, sebenarnya tidak semata-mata hanya permasalahan ekonomi saja. Namun pemerintah begitu konsentrasi terhadap permasalahan ekonomi, karena kondisi ekonomi yang mapan dapat berdampak ke sektor non-ekonomi lainnya. Misalnya saja pendidikan, angka kriminalitas menurun iklim politik lebih sehat. Sektor-sektor ini semuanya tidak bisa dilepaskan dari kondisi ekonomi suatu negara.

Manusia sebagai pelaku ekonomi tentunya memiliki kemampuan yang berbeda-beda dalam rangka memenuhi kebutuhannya sehari-hari. Hal ini tentu saja dapat menciptakan kemiskinan dan ketimpangan secara masif pada suatu wilayah perekonomian. Di sini, pembahasan pemberian subsidi kepada masyarakat masuk ke dalam permasalahan sebagai sebuah solusi. Pemberian subsidi dianggap mampu berfungsi sebagai alat peningkatan daya beli masyarakat serta dapat meminimalisir ketimpangan akan akses barang dan jasa. Oleh karena itu, cita-cita kemakmuran suatu bangsa dapat dicapai salah satunya dengan kebijakan subsidi tersebut.Terlihat jelas bahwa peran pemerintah sangat memegang posisi penting akan keberlangsungan program subsidi.

Dalam konteks pemberian subsidi kepada pelaku usaha akan berdampak pada pengurangan biaya produksi yang ditanggung oleh pelaku usaha sehingga akan menurunkan harga di pasar. Penurunan harga akan memberikan keuntungan kepada konsumen. Besar kecilnya penurunan harga akibat subsidi selain ditentukan oleh elastisitas permintaan dan penawaran, juga ditentukan oleh struktur pasar dari barang tersebut. Oleh karenanya, kebijakan pemerintah dalam pemberian subsidi produksi yang berorientasi pada kesejahteraan konsumen selain harus

15 Taufik H Simatupang, "Aspek Hukum Pemberian Subsidi Oleh Negara Di Dalam Lalu Lintas Perdagangan Internasional”, Artikel Pada Jurnal Lex Jurnalica, Vol. 6 No.1 (Desember, 2008), h. 2526. 
memperhatikan karakteristik/ elastisitas permintaan dan penawaran, juga perlu memperhatikan struktur pasar dari barang tersebut. Sebagai suatu tempat atau proses interaksi antara permintaan (pembeli) dan penawaran (penjual) dari suatu barang/jasa tertentu, pasar dapat menetapkan harga keseimbangan (harga pasar). Dalam konteks ini, tingkah laku pelaku usaha dan pembeli banyak ditentukan oleh struktur pasar dimana proses interaksi tersebut terjadi. ${ }^{16}$

Disamping itu, harga ditingkat konsumen juga dipengaruhi oleh pola distribusi suatu barang semakin panjang saluran distribusi, maka akan semakin mahal harga yang dibeli oleh konsumen akhir. Harga kebutuhan pokok acapkali mengalami fluktuasi harga, sebab kebutuhan pokok merupakan salah satu komoditas pangan yang dibutuhkan oleh masyarakat banyak. sehingga dalam penentuan harga barang kebutuhan pokok didasarkan pada tiga keadaan yaitu pembentukan harga kebutuhan pada sat kondisi pasokan harga normal, saat pasokan barang sedang banyak dan pada saat pasokan barang sedikit/langka. Ketiga ini merupakan penyebab harga jual dari kebutuhan pokok yang diterapkan pedagang berbedabeda kepada konsumen. ${ }^{17}$

Dalam hal keadaan pasokan barang langka, terkadang disinilah spekulan melakukan aksinya. Biasanya para spekulan memanfaatkan kondisi kelangkaan barang dengan menimbun pasokan barang, agar harga barang semakin melonjak. Ketika harga melonjak tinggi para spekulan menjual ke pasar dengan harga yang jauh lebih tinggi. Dengan situasi seperti ini, pemerintah harus mengintervensi pelaku usaha agar harga yang melonjak tidak berjalan semakin lama.

Dalam APBN disebutkan bahwa jenis dari belanja subsidi terdiri dari dua macam yaitu subsidi energi dan subsidi non energi. Subsidi energi meliputi Subsidi Bahan Bakar Minyak (BBM), Subsidi Bahan Bakar Nabati (BBN), LPG tabung 3 $\mathrm{kg}$, LGV, subsidi listrik. Sedangkan subsidi non energi meliputi subsidi pertania di antaranya: subsidi pangan, subsidi benih, dan subsidi pupuk, subsidi bunga kredit program, Public Service Obligation (PSO), subsidi pajak/DTP, dan lainnya. ${ }^{18}$

Habib Nazir mengatakan bahwa subsidi adalah cadangan keuangan dan sumberdaya lainnya untuk mendukung suatu kegiatan usaha atau kegiatan perorangan oleh pemerintah. ${ }^{19}$ Dari pengertian tersebut dapat disimpulkan bahwa subsidi

16 Amril, "Dampak Pemberian Subsidi Produksi TerhadapKeseimbangan Pasar Pada Pasar Persaingan SempurnaDan Pasar Monopoli”, Jurnal Penelitian Universitas Jambi Seri Humaniora, Vol. 15, No. 2, Juli - (Desember, 2013), h. 41-52.

17 Toti Indrawati," Analisis Perilaku Pedagang dalam Pembentukkan Harga Barang Kebutuhan Pokok di Kota Pekanbaru," Jurnal EKONOM, Vol. 21, No.1 (Maret 2013), h. 15-16.

18 Dungtii Munawar, Widyaiswara Utama BDK Cimahi, Memahami Pengertian dan Kebijakan Subsidi dalam APBN, diakses tanggal 8 Mei 2016.

19 digilib.unila.ac.id, diakses tanggal 8 Mei 2016 
adalah bantuan yang diberikan oleh Pemerintah dalam bentuk uang ataupun dalam bentuk lainnya (cadangan terhadap produk tertentu) kepada pelaku usaha penghasil kebutuhan pokok untuk membantu dan menunjang perkembangan usaha kelompok tani yang berkenaan dengan kepentingan publik.

Negara dalam membuat suatu kebijakan, tidak terlepas dari pemahaman dan persepsi masing-masing para pembuat kebijakan dan ideologi politik dari pembuat kebijakan. Sehingga pemahaman para pelaku pembuat kebijakan sangat menentukan keberhasilan dari suatu kebijakan yang ingin diterapkan. Sebab salah satu penyebab gagal atau tidaknya implementasi suatu kebijakan tersebut karena mereka tidak dapat memahami dengan benar kesalahan persepsi dari masing-masing pelaku disebabkan telah dicampuri dengan kepentingan pribadi dan politik.

Dengan demikian dibutuhkan suatu konsep untuk menangani permasalahan subsidi BBM ditanah air. Salah satu permasalahan subsidi BBM dapat diatasi melalui konsumsi BBM. Tidak efisiennya pemakaian BBM di sektor transportasi dimana mobil-mobil tua yang boros BBM. Selain itu, penggunaan mesin-mesin tua di industri, pemakaian solar yang terlalu besar untuk pembangkit tenaga listrik juga merupakan faktor borosnya BBM di Indonesia. Sehingga perlu kiranya dibuat suatu aturan yang lebih ketat agar pemakaian BBM oleh transportasi dan industri tua lebih efisien. ${ }^{20}$

Selain peningkatan efisiensi konsumsi BBM, substitusi BBM dengan sumber energi lain (gas bumi, batubara, dsbnya) sesungguhnya sangat terbuka untuk dilakukan di Indonesia, mengingat ketersediaan sumber-sumber energi alternatif dalam jumlah yang melimpah dan harga yang murah. Pembangunan infrastruktur energi, Sumber-sumber gas bumi dan batubara yang terletak dalam jarak yang jauh perlu dihubungkan dengan pusat-pusat konsumsi energi yang sebagian besar berada di Jawa. Perencanaan pembangunan infrastruktur energi merupakan langkah strategis untuk mewujudkan hal itu. Dibandingkan dengan beban subsidi BBM yang ditanggung Pemerintah (yang telah melewati batas akal sehat), maka biaya pembangunan infrastruktur penyaluran energi tidak terlalu mahal. ${ }^{21}$

Selain konsep di atas, untuk menangani permasalahan subsidi BBM di tanah air. Menurut hemat penulis pemberian subsidi untuk masyarakat miskin sangat perlu, namun disesuaikan dengan kemampuan keuangan suatu negara atau keuangan suatu daerah dalam memberikan subsidi. Selain itu diperlukan pengawasan oleh pemerintah atau orangyang berwenang di setiap SPBU agar subsidi tepat sasaran.

20 Hanan Nugroho, "Apakah persoalannya pada subsidi BBM? Tinjauan terhadap masalah subsidi BBM, ketergantungan pada minyak bumi, manajemen energi nasional, dan pembangunan infrastruktur energi," Jurnal Perencanaan Pembangunan No. 02 (2005), h. 16-17.

21 Hanan Nugroho, "Apakah persoalannya pada subsidi BBM?," h. 16-17. 
Adanya pengaturan anggaran bagi investor asing, diperlukan adanya pengaturan yang adil untuk memancing perusahaan asing sebagai pemasuk keuangan negara yang berdasarkan hukum. Dengan demikian modal yang diinvestasikan dapat menjadi keuntungan bagi perekonomian nasional sehingga dapat memberikan kesejahteraan pada rakyat banyak. Namun yang lebih penting dalam membuat kebijakan adalah mengedepankan hukum. Hukum yang memuat keadilan. Hukum tetap harus dijadikan sebagai panglima (supremacy of law) yang harus dipatuhi sehingga tujuan hukum dalam UUD 1945 akan terealisasi.

Ada banyak kebijakan pemerintah yang berkenaan dengan pemberian subsidi yang di antaranya harga BBM. Hal ini mengingat BBM sebagai sebuah komoditi yang strategis dan berkenaan akan kepentingan publik. Tingginya harga pasar minyak tidak diikuti dengan daya beli masyarakat yang baik. Berbagai upaya dilakukan pemerintah untuk meredistribusi pendapatan guna mengurangi kesenjangan antar anggota masyarakat. Program-program yang ditetapkan tidak jarang menuai kritikan di antara pihak yang berseberangan dengan kepentingan.

Kebijakan memberikan subsidi oleh suatu negara, jika dipandang perspektif dalam hubungan internasional mengalami permasalahan. umumnya pemerintah di banyak negara berkembang takut memberikan subsidi, karena tidak paham dan tidak ingin dipermasalahkan di WTO. Padahal, sepanjang memenuhi tolok ukur dan dapat menunjukkan bahwa kebijakan subsidi tidak merugikan anggota WTO yang lain, maka negara tersebut dapat memberikan subsidi guna meningkatkan daya saing pelaku usaha dan eksportirnya. ${ }^{22}$

Di dalam perdagangan internasional subsidi dianggap sebagai salah satu bentuk persaingan curang dan dapat mengacaukan mekanisme pasar. Karena itu, penggunaan subsidi dibatasi agar tidak menimbulkan hal-hal yang dapat mengganggu negara lain. ${ }^{23}$ Pemberian subsidi oleh negara dianggap dapat merugikan WTO karena berbenturan dengan peraturan yang telah dibentuk. Agreement on Agriculture-AoA merupakan salah satu peraturan yang membahas tentang hasil perdagangan pertanian. Dalam peraturan tersebut terdapat dua unsur utama dalam hal pemberian subsidi. Pertama, untuk negara-negara maju, subsidi ekspor harus dikurangi sebanyak $21 \%$ dari volume ekspor dan 36\% dari nilai subsidi per produk kepada para petani mereka. Sedangkan negara-negara berkembang harus mengurangi subsidi ekspor $14 \%$ dari volume ekspor dan $24 \%$ dari nilai subsidi per produk. Kedua, setiap negara harus menjamin adanya akses pasar bagi hasil

22 Hira Jhamtani, WTO dan Penjajahan Kembali Dunia Ketiga (Yogyakarta: INSIST Press, 2005), h. 35.

23 Taufik H Simatupang," "Aspek Hukum Pemberian Subsidi Oleh Negara Di Dalam Lalu Lintas Perdagangan Internasional”, h. 14. 
pertanian, melalui penurunan tarif.

Indonesia sebagai negara berkembang juga merasakan hal serupa dengan negara-negara berkembang lainnya. Nampaknya negara Indonesia kurang percaya diri akan kedaulatan negaranya untuk membuat suatu aturan subsidi yang efektif di Indonesia. Ketidak-bebasan suatu negara dalam mengatur kepentingannya sendiri, meskipun suatu kebijakan baik untuk negaranya namun beum tentu baik dalam hubungan internasional. Hal ini terjadi akibat dari pemahaman masyarakat dan negara akan defenisi kedaulatan. Sebagaimana yang dikatakan Jean Bodin ${ }^{24}$ bahwa dari aspek internnya kekuasaan suatu negara dalam mengatur negaranya hanya dalam batas-batas lingkungan wilayahnya. Sementara kedaulatan dari aspek eksternnya menurut Boer Mauna, ${ }^{25}$ kebebasan suatu negara untuk melakukan berbagai kepentingan-kepentingannya dibatasi dengan tidak bertentangan hukum internasional. Dengan demikian dapat dikatakan bahwa hukum internasional mempunyai keduduka yang lebih tinggi.

Pemahaman kedaulatan yang berbeda-beda jelas turut menentukan fungsi dari kedaulatan suatu negara. Sehingga perlu diketahui apa saja yang termasuk dari suatu kedaulatan dan yang tidak termasuk dalam kedaulatan. Karena itu, dalam mengambil suatu kebijakan agar tidak bertentangan dengan hukum internasional.

Dalam hubungan internasional suatu negara akan dihadapkan kepada plus dan minus. Jika kebijakan suatu negara berbanding lurus dan tidak kontras dengan aturan hukum internasional maka akan menjadi suatu nilai yang baik. Akan tetapi minusnya adalah jika suatu aturan hukum internasional sangat kontras dengan kebijakan dalam negeri, inilah yang akan menjadi persoalan yang menghambat kebijakan-kebijakan yang akan diterapkan. Karena seringkali hukum internasional yang dibentuk kurang mempertimbangkan terhadap apa yang diinginkan oleh suatu negara berkembang khususnya Indonesia.

2. Operasi Pasar

Kebijakan intervensi lainnya adalah melakukan operasi pasar dengan melepas stok pangan nasional. Operasi pasar merupakan salah satu strategi yang diyakini dapat menekan harga barang di pasar. Operasi pasar disebut juga dengan pasar murah. Operasi pasar digelar jika harga kebutuhan pokok sangat tinggi. Hal ini disebabkan ketersediaan barang tersebut di pasar terbatas. Untuk mengatasi hal demikian, pemerintah melakukan operasi pasar yaitu dengan harga normal dan persediaan yang besar. Jika persediaan barang di pasar mencukupi dan kebutuhan

24 Muhammad Nur Islami,' Intervensi Hukum Internasional Dalam Kedaulatan Negara Republik Indonesia," Jurnal Media Hukum, Vol. 18, No. 1 (Juni 2011), h. 167.

25 Muhammad Nur Islami, "Intervensi Hukum Internasional," h. 168. 
masyarakat juga sudah terpenuhi, maka harga pasar pun akan kembali normal. Pada umumnya opersai pasar ini dilakukan, bila harga kebutuhan pokok tinggi dan kelangkaan pada stok komoditas pangan. Di antara kebutuhan pokok itu adalah beras, gula, minyak goreng, dan lain sebagainya.

Beras misalnya merupakan kebutuhan pokok manusia, merupakan komoditas pangan yang sering kali mengalami kenaikan harga. Sehingga tidak berlebihan jika pemerintah melalui lembaga BULOG seringkali melakukan operasi pasar dengan pemerintah setempat. Terlebih jika menjelang hari-hari besar Islam, seperti menjelang ramadhan, Idul fitri dan Idul Adha.

Peneliti Mubyarto dari Institute Yogyakarta yang bergerak dalam ekonomi kerakyatan, Istianto Ari Wibowo mengatakan, fenomena tersebut sudah menjadi agenda rutin. "seperti saat Hari Raya Idul Adha, harga kambing dan sapi naik. Kenaikannya sering kali tidak masuk akal”. Setiap tahun, menurutnya, selalu saja ada fenomena itu. Hal ini membuktikan bahwa pemerintah tidak pernah belajar dari pengalaman yang sudah-sudah."Bahkan kelangkaan barang sering kali terjadi. Sudah berpuluh tahun seperti ini. Kalau belajar, bisa diantisipasi. Diperkuat sisi suplainya, Operasi pasar yang biasa dilakukan pemerintah untuk bisa menekan harga, menurutnya, tak terlalu efektif. Tidak akan mampu mengendalikan harga, karena fenomena ini berlangsung serentak di seluruh wilayah Indonesia. Kalaupun pemerintah melakukan dropping ke puluhan ribu titik daerah yang mengalaminya pun, terlalu banyak memakan anggaran. ${ }^{26}$

Pengaturan jenis barang kebutuhan pokok dan barang penting dapat kita temukan dalam Pasal 2 ayat (6) Peraturan Presiden No. 7 Tahun 2015 tentang Penetapan dan Penyimpanan Barang Kebutuhan Pokok dan Barang Penting. Sebanyak 18 jenis barang yang masuk kategori Barang Kebutuhan Pokok adalah: beras, kedelai bahan baku tahu dan tempe, cabe, bawang merah, gula, minyak goreng, tepung terigu, daging sapi, daging ayam ras, telur ayam ras, ikan segar yaitu bandeng, kembung dan tongkol/tuna/cakalang.benih yaitu benih padi, jagung, dan kedelai, pupuk, gas LPG 3 (tiga) kilogram, triplek, semen, besi baja konstruksi, baja ringan.

Barang kebutuhan pokok dan barang penting yang tidak diatur dalam Pasal diatas diatur oleh peraturan yang lain sebagaimana disebutkan dalam Pasal 2 ayat (7) Jenis Barang Kebutuhan Pokok dan/atau Barang Penting sebagaimana dimaksud pada ayat (6) dapat diubah berdasarkan usulan Menteri setelah berkoordinasi dengan menteri/kepala lembaga pemerintahnonkementerian terkait. Seperti BBM termasuk kategori barang nenting diatur dalam nenielasan Pasal 25 UU 26 http://daerah.sindonews.com, Operasi Pasar Tak Efektif Tekan Harga, diakses tanggal, 10 Mei 2016. 
No. 7 Tahun 2014 tentang Perdagangan.

Bagaimana kemudian mekanisme operasi pasar sehingga dapat menetapkan harga melalui intervensi harga. Salah satu kebutuhan pokok yang sering mengalami kenaikan harga adalah beras. BULOG merupakan salah satu perusahaan umum miliki negara yang bergerak dalam perdagangan komoditi yang tugasnya adalah menjaga stabilisasi harga pangan. BULOG beserta jajaran terkait seringkali melakukan operasi pasar ketika harga kebutuhan pokok melonjak tinggi. Operasi pasar dilakukan dengan terlebih dahulu menentukan lokasi, kemudian menentukan harga penjualan beras dengan menyesuaikan harga di pasar. Pada umumnya harga yang ditetapkan BULOG sama dengan harga pasar sebelum mengalami kenaikan. Hal ini dilakukan agar harga di pasar kembali stabil. Penjualan beras pada saat operasi pasar dapat dijual kepada pelaku usaha dengan harga yang lebih murah, sehingga pelaku usaha menjual kepada konsumen pun dengan harga yang jauh lebih murah.

Operasi pasar yang dilakukan pemerintah terhadap komoditi beras melalui mekanisme harga yang menurut Meier digolongkan pada pendekatan productive state. Peran pemerintah ditujukan untuk memperbaiki kegagalan pasar dan bentuk intervensi tidak bersifat langsung melainkan melalui mekanisme harga. Setelah pasar bekerja dengan normal, maka intervensi pemerintah akan ditarik kembali. Kebijakan yang muncul didasarkan untuk kesejahteraan masyarakat luas. Intervensi melalui mekanisme penetapan harga dilakukan dengan mempengaruhi tingkat harga di pasar. Pola pelaksanaan intervensi tersebut adalah dengan cara:

(a) Membeli beras produsen pada saat terjadinya musim panen dan menyimpannya menjadi buffer stole atau melakukan pengadaan beras melalui impor apabila tingkat produksi petani tidak bisa menutupi kekurangan konsumsi.

(b)Melepaskan cadangan pada saat terjadinya musim kemarau (kelangkaan beras). ${ }^{27}$

Kebijakan operasi pasar yang dilakukan oleh pemerintah telah diatur dalam Peraturan Menteri Perdagangan Republik Indonesia No 04/M-DAG/PER/1/2012 Tentang Penggunaan Cadangan Beras Pemerintah Untuk Stabilisasi Harga. Dalam aturan tersebut dijelaskan bahwa jika terjadi lonjakan harga $10 \%$ atau lebih terhadap harga normal yang berlangsung paling sedikit 1 minggu dan/atau dapat meresahkan masyarakat berdasarkan dari laporan pemerintah setempat, maka pemerintah dapat melakukan operasi pasar dengan menggunakan beras dari cadangan beras pemerintah. Biasanya yang melakukan operasi pasar adalah PERUM BULOG atas instruksi Menteri setelah menerima usulan gubernur dan/atau rekomendasi

27 Suharmen, Analisis dampak subsidi beras terbadap kesejabteraan, UI, diakses tanggal, 10 Mei 2016. 
dari Menteri Pertanian selaku Ketua Harian Dewan Ketahanan Pangan.

Dalam melakukan operasi ada dua tujuan yang ingin dicapai yaitu pertama membantu masyarakat tidak mampu untuk membeli barang dengan harga murah dan sebagai pendulum untuk menekan harga barang. Kedua, Pasar murah diharapkan bisa menjadi sarana pemerintah untuk memberikan efek psikologis kepada para pedagang, pemasok, maupun konsumen agar tidak mengikuti ekspektasi inflasi terhadap harga sejumlah kebutuhan pokok. Perlu adanya kontrol dan pengawasan yang ketat dalam agenda operasi pasar, agar kebutuhan pokok bisa didistribusikan secara merata ke semua tempat. Selain itu, untuk mengantisipasi adanya kecenderungan sekelompok pihak yang ingin memanfaatkan momen seperti Ramadhan dan lebaran sebagai moment untuk mengais keuntungan sebesar-besarnya. ${ }^{28}$

Menurut Jayne ada beberapa faktor penyebab tidak stabilnya harga beras di antaranya: pertama, goncangan pasokan dipasar domestik. Kedua, perubahan kebijakan pemerintah, dan ketiga goncangan harga di pasar internasional..$^{29}$ Dengan merujuk pendapat Jayne salah satu faktor penyebab naiknya harga di pasar adalah adanya kekurangan pasokan beras dan adanya permainan spekulan. Lonjakan harga ini dapat diatasi jika pemerintah membuat suatu kebijakan dan hukum ekonomi yang mumpuni. Salah satu kebijakan tersebut adalah adanya operasi pasar. Operasi pasar dapat menekan harga disebabkan bertambahnya volume pasokan di pasar sehingga dapat menurunkan harga beras. Hal Ini dapat efektif apabila pihak yang berwenang melakukan operasi pasar ketika pasokan beras di pasar menurun. Namun dapat juga menjadi berpengaruh negatif bagi pelaku usaha beras jika operasi pasar dilakukan ketika pasokan beras normal.

\section{Pengaturan Tarif Bea Masuk Impor}

Dalam rangka mewujudkan kesejahteraan sebesar-besarnya bagi masyarakat banyak dan keadilan sosial serta untuk menstabilkan harga di pasar, maka pemerintah melakukan pengaturan tarif bea masuk impor. Namun pemerintah merasa kebingungan Apakah menerapkan bea tarif masuk yang tinggi atau menurunkannya. Jika menaikkan tarif bea masuk impor yang tinggi maka akan membuat barang impor menjadi mahal ketika sampai di Indonesia sehingga menambah beban bagi para konsumen khususnya masyarakat miskin dan mengakibatkan stok barang mengalami kelangkaan. Namun jika menetapkan biaya tarif yang rendah, dikhawatirkan pelaku usaha domestik tidak dapat bersaing disebabkan harga

28 Casmudi, Kontrol dan Pengawasan Ketat Free Market System (Sistem Pasar Bebas) Menjadikan Harga Stabil di Bulan Ramadhan dan Hari Raya, diakses tanggal, 10 Mei 2016.

29 Ranni Resnia dan Astari Wirastuti, "Kebijakan Stabilisasi Harga Pasar," Jurnal Litbang Perdagangan, Vol. 3, No. 1 (Juli 2009), h. 6. 
barang impor lebih murah dibandingkan harga barang domestik. Operasi ini dalam konteks syariah disebut tasir (penetapan harga komoditas).

Bagi sebagian ulama, pemerintah berhak memaksa para pedagang yang melakukan monopoli untuk menjual barang dagangannya dengan harga standar yang berlaku di pasar. Bahkan barang yang ditimbun harus dijual dengan harga modalnya tanpa mengambil keuntungan sebagai hukuman atas tindakan monopoli tersebut. Bahkan bagi pemerintah berhak menyita barang tersebut dan membagibagikannya kepada masyarakat yang sangat memerlukan apabila pedagang yang melakukan ihtikar enggan menjual dagangannya sesuai harga pasar. ${ }^{30}$

Berbicara mengenai efektifitas pengaturan tarif bea masuk impor sudah lama diperdebatkan di negara Indonesia. Nampaknya pemerintah mengalami kebingungan tentang kebijakan apa yang harus diambil. Menaikkan atau menurunkan atau bahkan menghapus bea masuk impor. Demikian juga dengan masyarakat, ada yang memandang bahwa impor itu diperlukan untuk menjaga stabilitas harga dan kebutuhan dalam negeri, namun terdapat juga yang kontra memandang bahwa dikhawatirkan para pelaku usaha domestik tidak dapat bersaing. Namun hakikatnya semua itu menurut penulis harus dipertimbangkan dengan matang sesuai dengan situasi dan kondisi.

Pada tahun 2011 pemerintah Indonesia mengambil kebijakan membebaskan bea masuk untuk 57 komoditas pangan, di antaranya adalah beras. Agus Martowardojo, Menteri Keuangan, telah mengeluarkan Peraturan Menteri Keuangan No 13 Tahun 2011 yang secara resmi membebaskan bea masuk 57 pos tarif dari empat komoditas pangan mulai 1 Januari 2011.

Pembebasan mengenai bea masuk pangan tersebut bukan tanpa alasan, pertama, pemerintah berharap pembebasan bea masuk garam tersebut dapat membantu pengusaha yang mengalami tekanan bahan baku impor karena adanya lonjakan harga di pasar internasional. Kebijakan bea masuk pangan dan pupuk akan disesuaikan dengan harga komoditas di pasar internasional. Oleh karena itu, peraturan menteri keuangan itu menyebutkan, jika harga komoditas pangan dan pupuk di dalam negeri tidak lagi membutuhkan kebijakan stabilisasi harga, 57 pos tarif keempat komoditas pangan itu akan dikenakan bea masuk sebesar 5\% yang rencananya akan diterapkan mulai 1 Januari 2012. ${ }^{31}$

30 Perdebatan lebih jauh mengenai tas'ir (penetapan harga) selengkapnya baca: Muhammad Sayyid Tanthawi, Ijtihad dalam Teologi Keselarasan (Michigan: Universitas Michigan, 2005), h. 88-95. Ahmad Ifham Sholihin, Buku Pintar Ekonomi Syari'ah (Jakarta: Gramedia Pustaka Utama, 2013), 381-384. Evra Willya, "Ketentuan Hukum Islam Tentang At-Tas'ir Al-Jabari”, Jurnal Ilmiah al-Syari'ah, Vol. 11, No. 2 (2013), h. 1-42.

31 http://kanopieconjournal.blogspot.co.id, Wildan Noor Ramadhan, Polemik Impor Garam di 
Kepala Badan Kebijakan Fiskal (BKF) Kementerian Keuangan Bambang Brodjonegoro mengatakan, pembebasan bea masuk komoditas pangan ini bertujuan melancarkan ketersediaan pasokan pangan di dalam negeri. "Karena ada kemungkinan pasokan domestik tak mencukupi sehingga dibutuhkan impor," ujarnya. Dia menambahkan, sasaran akhir dari kebijakan ini adalah menurunkan inflasi. Lebih lanjut, Bambang mengatakan pemerintah sudah membebaskan bea masuk impor beras menjadi Rp 0 per kilogram $(\mathrm{Kg})$. Namun ketentuan ini hanya berlaku hingga akhir Maret 2010. Sehingga setelah Maret, tarif bea masuk beras berlaku kembali, yakni sebesar Rp 450 per kg. Dengan kebijakan ini, pendapatan negara dari bea masuk impor akan berkurang. Pemerintah harus memilih antara kehilangan bea masuk dengan inflasi. "Kalau bea masuk berdampak hanya pada sektor penerimaan negara, maka dalam hal inflasi masyarakat yang merasakan langsung dampaknya. Guru Besar Fakultas Ekonomi Institut Pertanian Bogor (IPB), Hermanto Siregar berpendapat, pembebasan bea masuk ini dalam jangka pendek efektif mengerem inflasi di 2011. Karena empat komoditas yang diimpor memang tak dapat diproduksi langsung di Indonesia. Gandum misalnya bisa menggantikan fungsi beras, seperti diolah menjadi mie dan roti.

Sejak kenaikan harga beras di pasar dunia, pemerintah merancang sejumlah kiat untuk meredam kenaikan harga beras dalam negeri. Salah satu diantaranya "melarang" ekspor beras dan penurunan bea masuk. Peraturan Mendag (No.12/MDAG/PER/4/2008) tentang ketentuan Impor dan Ekspor yang dikeluarkan April 2008, menyebutkan (dalam Pasal 10) bahwa "ekspor beras hanya dapat dilakukan apabila persediaan beras dalam negeri telah melebihi kebutuhan...”. Ekspor beras hanya dapat dilakukan oleh Bulog. Walaupun tidak ada ketetapan tentang angka besaran persediaan beras di dalam negeri, sehingga Bulog boleh melakukan ekspor beras. Namun, pemerintah secara lisan memperbolehkan Bulog mengekspor, apabila stok akhir tahun mencapai 2,5 juta ton. Hal ini merupakan angka mustahil, karena sulitnya pengadaan beras dalam negeri serta penyaluran untuk Raskin yang tinggi. ${ }^{32}$

Sekitar tahun 1990-an, para pejabat tinggi ASEAN meluncurkan gagasan baru, yaitu mewujudkan suatu pasar bersama yang terintegrasi dan bebas hambatan yang dinamakan AFTA (ASEAN Free Trade Area). Resminya skema kesepakatan yang diberi judul "The Agreement on Common Effective Preferential Tariff(CEPT) Scheme for the ASEAN Free Trade Area". Kesepakatan ini dihasilkan dalam sidang ke-4 ASEAN Summit di Singapura tanggal 28 Januari 1992 dan menyatakan

Indonesia, diakses, tanggal 13 Mei 2016.

32 Ranni Resnia dan Astari Wirastuti, "Kebijakan Stabilisasi Harga Pasar," Jurnal Litbang Perdagangan, Vol. 3, No. 1 (Juli, 2009), h. 6. 
kesepakatan bahwa dengan menggunakan skema CEPT sebagai kesepakatan utama, yaitu program penurunan tarif bea masuk untuk 15 kelompok produk secara bertahap antar negara ASEAN hingga pada tahun 2008 kelak tarif bea masuk antar negara ASEAN menjadi 0 sampai 5 persen saja. Pembatasan kuantitatif dan hambatan non tarif juga dieliminasi hingga tercapainya status free trade area yang sudah mulai sejak tahun 2002. ${ }^{33}$

Perkembangan tarif bea masuk untuk 15 kelompok produk ${ }^{34}$ tahun 2001 sampai 2010 mengalami penurunan. Pada tahun 2001 bea tarif sebesar 2,81\%. Pada tahun 2002 mengalami kenaikan sebesar 3,89\% dan pada tahun-tahun selanjutnya sampai pada tahun 2010 besar bea tarif $1,99 \% .{ }^{35}$ Dilihat perkembangan tarif bea masuk di atas cenderung mengalami penurunan. Penurunan tarif bea masuk untuk 15 kelompok produk akan mengakibatkan volume impor meningkat. Hal ini akan membawa pengaruh buruk bagi perkembangan industri di Indonesia karena barang-barang hasil dalam negeri akan kalah saing dengan produk impor yang harganya jauh lebih murah.

Namun yang paling terpenting adalah dilakukan sesuai dengan situasi dan kondisi, karena pada dasarnya kebijakan pembebasan bea masuk sejumlah barang dimaksudkan untuk menjaga daya saing industri domestik, meskipun kebijakan itu berpotensi menurunkan pendapatan negara. Jika dikaitkan dengan saat ini dan jika tujuannya adalah untuk menciptakan sebesar-besarnyaa kesejahteraan masyarakat Indonesia maka wajar jika tarif bea masuk impor beras tidak Rp. 450/Kg atau lebih. Semua ini pada hakikatnya bertujuan untuk melindungi dan perdayaan para petani domestik dan melindungi komoditas domestik sebagaimana dijelaskan dalam UU No. 19 Tahun 2013 tentang Perlindungan dan Pemberdayaan Petani. Aturan ini menjelaskan bahwa petani perlu diberi perlindungan dan pemberdayaan untuk mendukung kemampuan petani dalam memenuhi kebutuhan panganyang berkelanjutan.

Sementara untuk melindungi petani maka kebijakan yang dapat dilakukan adalah menetapkan tarif bea masuk komoditas pangan atau pertanian. Pasal 7 ayat 2 huruf c dan Pasal 25 UU No.19 Tahun 2013 Tentang Perlindungan dan Pemberdayaan Petani menyebutkan bahwa salah satu kebijakan untuk melindungi

33 I Made Aryana, Pengarub Tarif Bea Masuk, Kurs dan Volume Impor Terhadap Penerimaan Bea Masuk Di Indonesia, Tesis, Program Pascasarjana Universitas Udayana, Denpasar, 2011, h. 7.

34 Lima belas kelompok produk tersebut adalah semen, pupuk, pulp, tekstil, perhiasan dan permata, perabot dari kayu dan rotan, barang kulit, plastik, obat-obatan, elektronika, kimia, produk karet, minyak nabati, gelas keramik, dan katoda tembaga.

35 I Made Aryana, Pengarub Tarif Bea Masuk, Kurs dan Volume Impor Terhadap Penerimaan Bea Masuk Di Indonesia, Tesis, Program Pascasarjana Universitas Udayana, Denpasar, 2011. 
petani adalah melalui penetapan tarif bea masuk. ${ }^{36}$ Pada Pasal 26 ayat 3 juga dijelaskan bahwa penetapan besaran tarif bea masuk diharapkan dapat mendorong peningkatan produksi dalam negeri. Indikasi dari pasal tersebut menunjukan bahwa dibutuhkan kejelian pemerintah untuk menetapkan tarif bea masuk pertanian yang dapat meningkatkan produksi dalam negeri dan menguntungkan para petani.

4. Penetapan Harga Pembelian Pemerintah (HPP)

Salah satu masalah klasik yang sering dialami petani padi adalah menurunnya harga jual gabah/beras pada saat panen raya, dan meningkatnya harga pada saat di luar panen. Kondisi tersebut menyebabkan petani menjadi rugi dan usaha tani padi tidak menguntungkan. Selain itu, kenaikan harga beras dapat menimbulkan gejolak sosial mengingat beras merupakan makanan pokok masyarakat Indonesia. Oleh karena itu, pemerintah berupaya membuat regulasi/kebijakan per-berasan agar gabah/beras petani dibeli dengan harga tertentu yang bisa memberikan keuntungan yang layak bagi petani. Lain dari itu, beras dijual ke masyarakat/ konsumen diatur dengan harga tertentu sehingga masyarakat mampu mengakses dalam batas wajar. Kebijakan tersebut dikenal dengan istilah Harga Pembelian Pemerintah (HPP) procurement price policy.

Kebijakan HPP gabah sudah dimulai sejak musim tanam 1969/70 (Sawit 2001). Pada jaman pemerintahan Orba, kebijakan ini dikenal dengan Harga Dasar Gabah (HDG) yang merupakan padanan dari floor price. Apabila harga gabah di bawah HDG, pemerintah berkewajiban melakukan pembelian gabah sesuai HDG, agar harga gabah meningkat di atas HDG.

Sejak2001, ketentuan HDG diganti dengan kebijakan Harga Pembelian Pemerintah (HPP),yangditentukan berdasarkan banyak faktor-faktoruntukmemberikan perlindungan bagi produsen dan konsumen beras. Spirit dari kebijakan ini sama dengan HDG, yaitu mengendalikan harga gabah di tingkat petani agar tidak jatuh dan tidak merugikan petani. ${ }^{37}$

Dalam menanggulangi gejolak harga di pasar, pemerintah telah mengeluarkan beberapa instrumen kebijakan jangka pendek yang pada intinya dimaksudkan untuk mencegah terjadinya gejolak harga. Kebijakan tersebut antara lain adalah; pertama penetapan harga pembelian pemerintah (HPP) untuk padi/beras; dan kedua pengenaan tarif, kuota, dan pengaturan waktu impor serta operasi pasar

36 M. Zainul Abidin, Dampak Kebijakan Impor Beras Dan Ketahanan Pangan Dalam Perspektif Kesejabteraan Sosial, (Jakarta:Kementerian Keuangan), 216, diakses tanggal 13 Mei 2016

37 Wayan Sudana," Efektivitas Penerapan Kebijakan Harga EceranTertinggi Urea dan Harga Gabah Pembelian Pemerintah di Beberapa Sentra Produksi Padi," Jurnal Iptek Tanaman Pangan, Vol. 6 No. 1 (2011), h. 32. 
untu komoditas tersebut. ${ }^{38}$

Penetapan HPP dilakukan dalam rangka meningkatkan pendapatan petani, pengembangan ekonomi pedesaan, stabilitas ekonomi nasional, peningkatan ketahanan pangan, dan dalam rangka pengadaan cadangan pangan. Selain itu, untuk mendukung peningkatan produktivitas petani padi dan produksi beras nasional.HPP gabah yang ditetapkan pemerintah diharapkan menjadi "semacam harga minimum"(floor price) yang berfungsi sebagai referensi harga (price reference) bagi petani dan pedagang yang melakukan transaksi jual-beli gabah/beras. Namun pada kenyataannya kesejahteraan petani tidak mengalami peningkatan. Petani merasa dirugikan oleh kebijakan tersebut. ${ }^{39}$ Maka diperlukan sebuah pengkajian tentang efektifitas HPP dilapangan apakah kebijakan tersebut dapat menekan lonjakan harga dan meciptakan kesejahteraan pada masyarakat.

Untuk mengetahui kebijakan penetapan HPP efektif atau tidak berikut penulis uraikan hasil kebijakan penetapan oleh Pemerintah dari tahun ke tahun. Penetapan HPP gabah/beras pertama kali dilakukan pada tahun 2002 yang dituangkan melalui Instruksi Presiden No.9 Tahun 2002. Pada tahun 2012, sudah 8 (delapan) kali ditetapkan kebijakan HPP gabah/beras untuk menyesuaikan situasi perberasan dalam negeri, terutama akibat perkembangan harga yang terus meningkat dari tahun ketahun. Selama periode tersebut, kenaikan HPP Gabah Kering Panen (GKP) berkisar 8-30 \% atau rata-rata 15,43\% per tahun, kenaikan HPP Gabah Kering Giling (GKG) berkisar 4-27 \% atau rata-rata 13,82 \% per tahun, dan HPP beras berkisar 0-30 \% atau rata-rata $15,90 \%$ per tahun, seperti Tabel 1.

Kebijakan HPP yang ditetapkan pemerintah dari tahun ke tahun selalu ditingkatkan. Pada Tabel 1 dapat dilihat bahwa kebijakan HPP oleh pemerintah selalu mengalami peningkatan. Mulai dari tahun 2002-2014 terjadi kenaikan yang signifikan. Kebijakan HPP ini lah yang dijadikan harga dasar penjualan gabah oleh petani. Artinya untuk melindungi petani maka harga gabah tidak boleh dijual dibawah harga dasar gabah yang telah ditetapkan pemerintah. Pada dasarnya penetapan kebijakan HPP oleh pemerintah adalah merupakan perlindungan petani melalui mekanisme penetapan harga.

Untuk melindungi petani sebagai pelaku usaha dan untuk membuat harga gabah atau beras stabil dengan tingkat harga yang terjangkau menurut Ilham diperlukan dukungan kebijakan lain, seperti perbaikan infrastuktur yang memadai

38 T.Muhammad Iqbal Johan, Faktor-faktor yang Mempengarubi Harga Pembelian Pemerintah (HPP) terhadap Beras di Sumatera Utara, Artikel, h. 3.

39 T. Muhammad Iqbal Johan, Faktor-faktor yang Mempengarubi Harga Pembelian Pemerintab (HPP) terbadap Beras di Sumatera Utara, h. 3. 
dan sistem pendistribusian yang lebih merata. Oleh sebab itu, perlu upaya atau regulasi untuk menekan marjin dari gabah keberas, agar harga beras ditingkat konsumen tidak terlalu mahal. ${ }^{40}$

5. Pembatasan Ekspor Pangan

Seperti pengaturan bea masuk impor diatas, pengaturan ekspor pangan juga menjadi perdebatan dikalangan para akademisi, pejabat maupun masyarakat. Apakah mengekspor pangan seperti beras menguntungkan para petani atau malah mengurangi stok pangan. Karena jika harga beras dunia naik, maka membuka keran ekspor akan menjadi keuntungan bagi para petani, namun melakukan ekspor beras juga membuat kekhawatiran pada pemerintah disebabkan akan berkurangnya stok pangan domestik sehingga akan berpengaruh pada harga. Sebab jika komoditas pangan mengalami kelangkaan akan membuat harga naik. Oleh karena itu mempertahankan stok beras dalam negeri lebih baik untuk mengantisipasi melonjaknya harga beras dalam negeri.

Pembatasan ekspor pangan di Indonesia telah dibahas dalam peraturan perUndang-Undangan. Salah satu aturan hukum yang membahas tentang pembatasan ekspor pangan adalah UU No. 18 Tahun 2012 tentang Pangan. UU ini mengandung prinsip-prinsip kedaulatan pangan dan kemandirian pangan yang membatasi impor dan ekspor makanan pokok, dan mendirikan otoritas makanan baru untuk menjamin persediaan pangan yang cukup. Pada Pasal 34 yang menyatakan bahwa "ekspor pangan negara hanya dapat dilakukan setelah kebutuhan-kebutuhan Cadangan Pangan Nasional dan kebutuhan konsumsi pangan dipenuhi.

Pembatasan ekspor pangan bertujuan agar stok pangan tersedia dan mencukupi kebutuhan masyarakat. Sebab jika stok pangan kurang maka harga kebutuhan pangan akan mengalami kenaikan. Dalam Pasal 1 angka (8) UU No. 18 Tahun 2012 tentang Pangan dijelaskan bahwa pemerintah menyediakan peresediaan pangan untuk seluruh wilayah Indonesia untuk menghadapi masalah kekurangan Pangan, gangguanpasokan dan harga, serta keadaan darurat. Dari peraturan ini jelas bahwasanya diperlukan pembatasan pada ekspor pangan ataupun eskpor lainnya, sebab yang diutamakan terlebih dahulu adalah kebutuhan dalam negeri jangan sampai mengalami kekurangan. Dengan demikian hakikat dari ekspor adalah jika kebutuhan dalam negeri telah cukup dan mempunyai cadangan yang cukup untuk diekspor.

Oleh karena itu, jika pemerintah mengambil kebijakan untuk mengekspor

40 Wayan Sudana, 'Efektivitas Penerapan Kebijakan Harga EceranTertinggi Urea dan Harga Gabah PembelianPemerintah di Beberapa Sentra Produksi Padi", Jurnal Iptek Tanaman Pangan, Vol. 6 No. 1 (2011): 22-23. 
beras, seyogyanya pemerintah melalui Menteri pertanian dan Bulog harus memastikan stok beras yang cukup, sehingga dalam mengekspor beras tidak menjadi momok bagi masyarakat indonesia. Karena itu, pada dasarnya tujuan kebijakan ekspor adalah agar kebutuhan dalam negeri dapat tercukupi dan mencegah kenaikan harga dalam negeri. Selain pembatasan ekspor pangan, pemerintah melalui Perum Bulog ekspor beras sebaiknya dilakukan dengan satu pintu, hanya Perum Bulog yang berwenang untuk melakukan ekspor beras. Keterlibatan pihak swasta dalam ekspor sebaiknya tidak diikutsertakan untuk mempermudah kontrol pemerintah dalam hal kualitas beras, volume ekspor serta tanggung jawabnya. Selain itu, sebaiknya pangan yang berhubungan dengan hajat hidup orang banyak seharusnya dikerjakan oleh pemerintah.

\section{Kriteria Penetapan Harga (Price Fixing) Oleh Negara Dalam Rangka Memberikan Perlindungan Hukum Kepada Konsumen dan Pelaku Usaha Lainnya Dalam Mewujudkan Persaingan Usaha Sehat}

Dalam kegiatan ekonomi suatu negara, pemerintah dibenarkan untuk campur tangan terhadap kegiatan ekonomi, salah satunya adalah penetapan harga. Dalam UUD 1945 pasal 33 ayat 2 dinyatakan bahwa cabang-cabang produksi yang penting bagi negara dan yang menguasai hajat hidup orang banyak dikuasai oleh negara. Secara umum dalam kegiatan penentuan harga di Indonesia sepenuhnya diserahkan kepada mekanisme permintaan dan penawaran, akan tetapi pada situasi dan kondisi tertentu pemerintah melakukan campur tangan dalam pengendalian harga.

Hal ini dilakukan dengan tujuan untuk melindungi kepentingan konsumen/ masyarakat dan pelaku usaha agar tidak merasa dirugikan. Seperti yang telah dijelaskan pada pembahasan sebelumnya ada beberapa bentuk campur tangan pemerintah dalam hal penetapan atau pengendalian harga seperti pemberian subsidi, operasi pasar, pengaturan tarif bea masuk impor, pembatasan ekspor pangan serta penentuan harga minimum dan maksimum kesemuanya ini bertujuan untuk menjaga stabilisasi harga di masyarakat, mencegah persaingan yang tidak sehat dan menciptakan kesejahteraan sebesar-besarnya bagi masyarakat. Menurut harini ada beberapa tujuan mengapa pemerintah menetapkan harga yaitu sebagai berikut: ${ }^{41}$ Penetapan harga untuk mencapai penghasilan atas investasi. Biasanya besar keuntungan dari suatu investasi telah ditetapkan prosentasenya dan untuk mencapainya diperlukan penetapan harga tertentu dari barang yang dihasilkannya.;

41 http://www.pendidikanekonomi.com, Pengertian, Dasar Penetapan dan Tujuan Penetapan Harga, diakses tanggal, 16 Mei 2016. 
Penetapan harga untuk kestabilan harga. Hal ini biasanya dilakukan untuk perusahaan yang kebetulan memegang kendali atas harga. Usaha pengendalian harga diarahkan terutama untuk mencegah terjadinya perang harga, khususnya bila menghadapi permintaan yang sedang menurun. Penetapan harga untuk mempertahankan atau meningkatkan bagiannya dalam pasar. Apabila perusahaan mendapatkan bagian pasar dengan luas tertentu, maka ia harus berusaha mempertahankannya atau justru mengembangkannya. Untuk itu kebijaksanaan dalam penetapan harga jangan sampai merugikan usaha mempertahankan atau mengembangkan bagian pasar tersebut. Penetapan harga untuk menghadapi atau mencegah persaingan. Apabila perusahaan baru mencoba-coba memasuki pasar dengan tujuan mengetahui pada harga berapa ia akan menetapkan penjualan. Ini berarti bahwa ia belum memiliki tujuan dalam menetapkan harga coba-coba tersebut. Penetapan harga untuk meminimalisir laba. Tujuan ini biasanya menjadi anutan setiap usaha bisnis. Kelihatannya usaha mencari untung mempunyai konotasi yang kurang enak seolah-olah menindas konsumen. Padahal sesungguhnya hal yang wajar saja. Setiap usaha untuk bertahan hidup memerlukan laba. Memang secara teoritis harga bisa berkembang tanpa batas.

Dengan demikian, jelas dikatakan bahwa persoalan penetapan harga memang menjadi persoalan penting bagi pemerintah untuk menerapkan harga yang wajar sehingga dapat melindungi konsumen dan pelaku usaha. Selain itu, mampu menciptakan kesejahteraan sebesar-besarnya bagi masyarakat melalui kebijakankebijakan yang efektif dan solutif. Sehingga jelas bahwa hanya barang-barang dan jasa-jasa yang menguasai hajat hidup orang banyak atau komoditas strategis yang pemerintah berhak menetapkan harganya. Hal ini bertujuan untuk menciptakan persaingan usaha yang sehat dan menciptakan keadilan ekonomi.

\section{Simpulan}

Pelaku usaha dalam menjalankan perekonomian belum sepenuhnya menerapkan apa yang diamanatkan oleh UUD yaitu Demokrasi Ekonomi. Yaitu menciptakan kesejahteraan sebesar-besarnya bagi konsumen dan pelaku usaha kecil. Masih banyak kecurangan-kecurangan yang dilakukan oleh pelaku besar dalam persaingan usaha yang ingin memperkaya diri sendiri tanpa memperhatikan kepentingan pelaku usaha kecil. Paradigma berbisnis seperti ini tentu bertentangan dengan perekonomian nasional yaitu keadilan ekonomi. Oleh sebab itu diperlukan peran pemerintah untuk memberikan perlindungan kepada konsumen dan pelaku usaha yaitu melalui penetapan harga. 
Beberapa bentuk mekanisme penetapan harga yaitu: pertama, Menetapkan Harga Eceran Tertinggi (HET) dan eceran terendah misalnya saja memberlakukan batasan toleransi kenaikan harga hanya $10 \%$ pada beras, jika diatas itu maka pemerintah memiliki kewenangan untuk memberikan sanksi. Kedua, pemberian subsidi (Harga/BLT) baik dalam bentuk uang ataupun dalam bentuk lainnya (cadangan terhadap produk tertentu) oleh pemerintah kepada pelaku usaha penghasil kebutuhan pokok untuk membantu dan menunjang perkembangan usaha kelompok tani yang berkenaan dengan kepentingan publik. Ketiga, Operasi Pasar atau disebut juga dengan pasar murah digelar jika harga kebutuhan pokok sangat tinggi. hal ini disebabkan ketersediaan barang tersebut di pasar terbatas. Keempat, Pengaturan Tarif Bea Masuk Impor ditujukan untuk mengatur penetapan tarif, kuota dari barang yang masuk. Pengaturan ini perlu untuk menjaga menjaga daya saing industri domestik dan perdayaan para petani domestik. Kelima, Penetapan Harga Pembelian Pemerintah (HPP) Gabah/Beras merupakan bentuk kebijakan agar gabah/beras petani dibeli dengan harga tertentu yang bisa memberikan keuntungan yang layak bagi petani. Keenam, Pembatasan Ekspor Pangan bertujuan untuk menjaga stabilisati stok komoditas pangan, jangan sampai terlalu banyak diekspor sebab dikhawatirkan akan membuat kelangkaan pada stok pangan dalam negeri sehingga nantinya akan membuat harga komoditas pangan dalam negeri akan mengalami kenaikan.

Penetapan harga oleh negara ditujukan pada barang dan jasa yang menguasai hajat hidup orang banyak sehingga mewujudkan maslahat bersama. Hal ini dilakukan untuk memberikan perlindungan kepada konsumen dan pelaku usaha agar tercipta amanat konstitusi yaitu menciptakan kesejahteraan sebesar-besarnya untuk rakyat dan menciptakan persaingan usaha yang sehat. Pihak swasta tak boleh memiliki power yang lebih dibanding negara, karena apabila ini terjadi maka akan berpotensi kepada kesewenang-kewenangan yang nantinya akan merugikan bangsa.

\section{Daftar Pustaka}

\section{Buku}

Amos, Abraham. Kastropi Hukum dan Quo Vadis, Jakarta: Raja Grafindo Persada, 2007.

Jhamtani, Hira. WTO dan Penjajahan Kembali Dunia Ketiga. Yogyakarta: INSIST Press, 2005.

Lauddin, Marsuni. Hukum dan Kebijakan Perpajakan di Indonesia, Yogyakarta:

UII Press, 2006. 
Marzuki, Peter Mahmud. Penelitian Hukum, Jakarta: Prenada Media Group, 2007. Muhammad, Abdulkadir. Hukum dan Penelitian Hukum, Cet. 1, Bandung: Citra Aditya Bakti, 2004.

Sayyid Tanthawi, Muhammad. Ijtihad dalam Teologi Keselarasan, Michigan:

Universitas Michigan, 2005.

Sholihin, Ahmad Ifham. Buku Pintar Ekonomi Syariah, Jakarta: Gramedia Pustaka Utama, 2013.

Sidabalok, Janus. Hukum Perlindungan Konsumen di Indonesia, Bandung: Citra Aditya Bakti, 2014.

Artikel

Amril, Dampak Pemberian Subsidi Produksi TerhadapKeseimbangan Pasar Pada Pasar Persaingan SempurnaDan Pasar Monopoli, Jurnal Penelitian Universitas Jambi Seri Humaniora, Volume 15, No. 2 (Juli-Desember, 2013): 41-52.

Evra Willya, "Ketentuan Hukum Islam Tentang At-Tas'ir Al-Jabari”, Jurnal Ilmiah al-Syariah, Vol. 11, No. 2 (2013): 1-42.

H Simatupang, Taufik. Aspek Hukum Pemberian Subsidi Oleh Negara Di Dalam Lalu Lintas Perdagangan Internasional, Jurnal Lex Jurnalica, Vol. 6 No.1, (Desember, 2008).

Hanan Nugroho, "Apakah persoalannya pada subsidi BBM? Tinjauan terhadap masalah subsidi BBM, ketergantungan pada minyak bumi, manajemen energi nasional, dan pembangunan infrastruktur energi," Jurnal Perencanaan Pembangunan No. 02 (2005).

Wahyu Siswanti, "Dinamika Implementasi Kebijakan Bantuan Langsung Tunai”, Artikel Pada Jurnal JKAP, Vol. 12 No. 1, (Mei, 2008)

Indrawati, Toti. "Analisis Perilaku Pedagang Dalam Pembentukkan Harga Barang Kebutuhan Pokok Di Kota Pekanbaru,"Jurnal EKONOM, Volume 21, No.1 (Maret, 2013). 
Islami, Muhammad Nur. "Intervensi Hukum Internasional Dalam Kedaulatan Negara Republik Indonesia," Jurnal Media Hukum, Vol. 18, No. 1, Juni, 2011.

Resnia Ranni dan Astari Wirastuti, “Kebijakan Stabilisasi Harga Pasar, Jurnal Litbang Perdagangan, Vol. 3, No. 1, (Juli, 2009)

Sudana, Wayan. "Efektivitas Penerapan Kebijakan Harga EceranTertinggi Urea dan Harga Gabah PembelianPemerintah di Beberapa Sentra Produksi Padi," Jurnal Iptek Tanaman Pangan, Vol. 6 No, (2011)

Tesis

Septiyaningrum, Erlina. Politik Hukum Persaingan Usaha Dalam Kerangka Demokrasi Indonesia (Suatu Kajian Sejak Orde Lama Hingga Orde Reformasi), Tesis, Program Pascasarjana Universitas Sebelas Maret, Surakarta, 2013.

Aryana, Made. Pengaruh Tarif Bea Masuk, Kurs dan Volume Impor Terhadap

Penerimaan Bea Masuk Di Indonesia. Tesis, Program Pascasarjana Universitas Udayana, Denpasar, 2011.

\section{Peraturan PerUndang-Undangan}

Undang-Undang Dasar 1945

Undang-Undang Nomor 8 Tahun 1999 tentang Perlindungan Konsumen

Undang-Undang Nomor 5 Tahun 1999 tentang Larangan Praktek Monopoli dan Persaingan Usaha Tidak Sehat

Undang-Undang Nomor 7 Tahun 2014 tentang Perdagangan

Undang-Undang Nomor 19 Tahun 2013 tentang Perlindungan dan Pemberdayaan Petani 